Int. J. Dev. Biol. 63: 271-280 (2019)

https://doi.org/10.1387/ijdb.180251sy

\title{
Definitive endoderm differentiation is promoted in suspension cultured human iPS-derived spheroids more than in adherent cells
}

\author{
SHIGEHARU G. YABE",1, JUNKO NISHIDA ${ }^{1}$, SATSUKI FUKUDA ${ }^{1}$, FUJIE TAKEDA ${ }^{1}$, KIYOKO NASHIRO $^{1}$, \\ MASATO IBUKI² and HITOSHI OKOCHI",1
}

Department of Regenerative Medicine, Research Institute, National Center for Global Health and Medicine, Tokyo, Japan and ${ }^{2}$ Regenerative Medicine and Cell Therapy Laboratories, Kaneka Corporation, Hyogo, Japan

\begin{abstract}
Human pluripotent stem cells (hPSCs), such as embryonic stem cells (ESCs) and induced pluripotent stem cells (iPSCs), are very attractive cell sources for the treatment of diabetes mellitus, because numerous cells can be obtained using their infinite proliferation potential to overcome the paucity of donor islets. Advances in differentiation protocols make it possible to generate glucose responsive hPSC-beta cells, which can ameliorate hyperglycemia in diabetic mice. These protocols have mainly been based on an adherent culture system. However, in clinical applications, suspension culture methods are more suitable for large-scale culture. There are reports that suspension culture and spheroid formation promote differentiation in various cell types, including hPSCs, but, to our knowledge, there are no reports comparing gene expression patterns between suspension and adherent cultured human iPSCs (hiPSCs) during definitive endoderm (DE) differentiation. In this study, we chose several stage marker genes, not only for DE but also for posterior epiblast and primitive streak, and we examined their time course expression in suspension and adherent cultures by quantitative PT-PCR (qPCR), western blot, flow cytometry and immunocytochemistry. Our results demonstrate that expressions of these marker genes are faster and more strongly induced in suspension culture than in adherent culture during the DE differentiation process, indicating that suspension culture favors DE differentiation.
\end{abstract}

KEY WORDS: definitive endoderm, pluripotent stem cell, induced pluripotent stem cell, adherent culture, suspension culture

\section{Introduction}

Islet transplantation is a very effective therapy forType1 diabetes, but many patients can't receive this treatment due to the shortage of donors. Human pluripotent stem cells (hPSCs) such as embryonic stem cells (ESCs) and induced pluripotent stem cells (iPSCs) may overcome this problem, because of their infinite proliferation potential and pluripotency, which allows them to produce all embryonic tissues. Over the last ten years, there has been great progress in methods to induce differentiation of hPSC-derived pancreatic beta cells (D’Amour et al., 2006, Maehr et al., 2009, Kunisada et al., 2012, Rezania et al., 2012). Moreover, these cells have been proven to secrete insulin in response to blood glucose level and normalize hyperglycemia in diabetic mice (Pagliuca et al., 2014, Rezania et al., 2014). Recently, we reported a 6-step differentiation protocol from hiPS cells into functional pancreatic beta cells (Yabe

Abbreviations used in this paper: BRA, brachyury; DE, definitive endoderm; EOMES, eomesodermin; FGF8, fibroblast growth factor 8; FOXA2, forkhead box protein A2; GSC, goosecoid; hiPSC, human induced pluripotent stem cell; HNF1B, hepatocyte nuclear factor 1 beta; HNF4A, hepatocyte nuclear factor 4 alpha; iPSC, induced pluripotent stem cell; MIXL1, mix paired-like homeobox;NANOG, nanog homeobox; NODAL, nodal growth differentiation factor; NGN3, neurogenin 3; OAZ1, ornithine decarboxylase antizyme; OCT3/4, PE, posterior epiblast; PDX1, pancreatic and duodenal homeobox 1; PGT, primitive gut tube; POU class 5 homeobox 1; PS, primitive streak; PSG, pluripotent stem cell; SOX2, SRY (sex determining region Y)-box 2; SOX17, SRY (sex determining region Y)-box 17.

*Address correspondence to: Shigeharu G. Yabe (syabe@ri.ncgm.go.jp) or Hitoshi Okochi (hokochi@ ri.ncgm.go.jp). Department of Regenerative Medicine, Research Institute, National Center for Global Health and Medicine, 1-21-1 Toyama Shinjuku-ku, Tokyo, Japan 162-8655. Tel: 81-3-3202-7181 Fax: 81-3- 3202-7192 (iD https://orcid.org/0000-0001-5377-5131 (Yabe) and (D) https://orcid.org/0000-0001-6938-7993 (Okochi).

Supplementary Material (7 figures) for this paper is available at: https://doi.org/10.1387/ijdb.180251sy

Submitted: 6 September, 2018; Accepted: 4 March, 2019; Edited by: Makoto Asashima.

ISSN: Online 1696-3547, Print 0214-6282

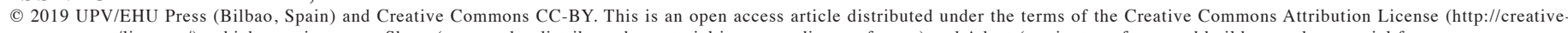

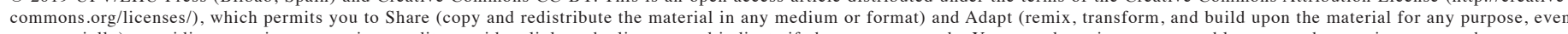

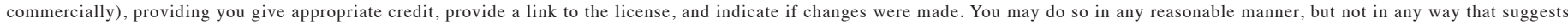
the licensor endorses you or your use. Printed in Spain 
A

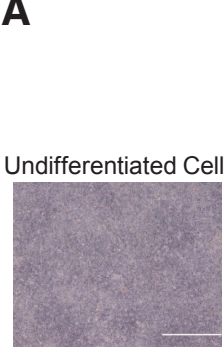

Adherent culture



Adherent culture


B

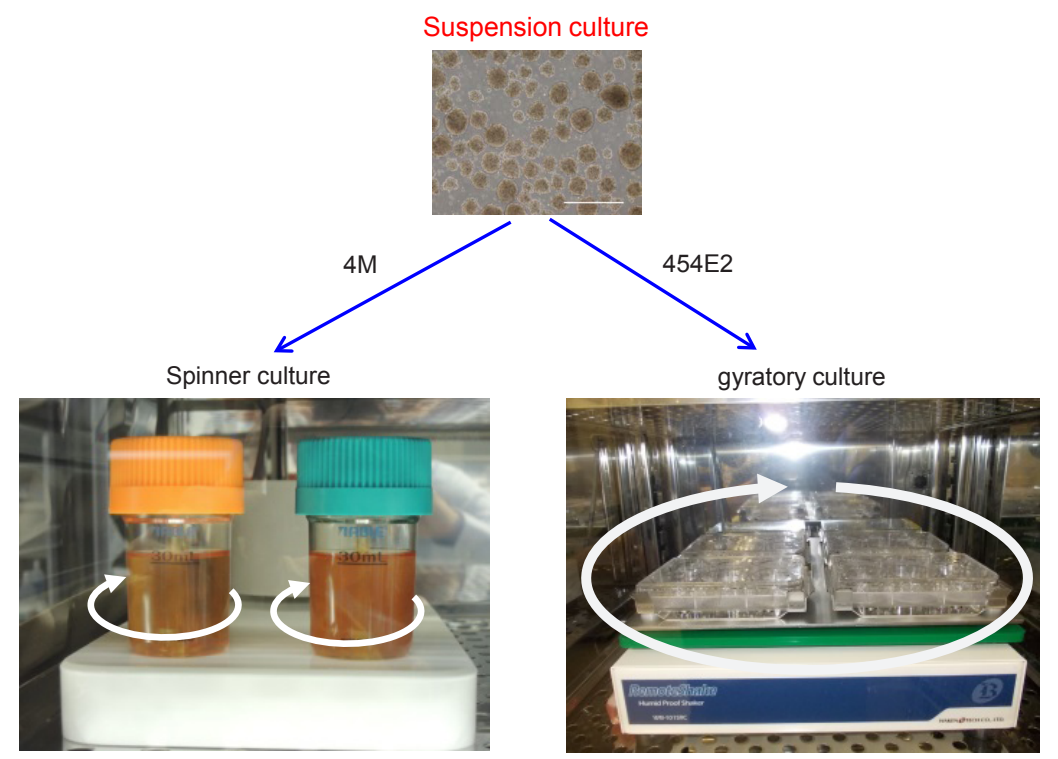

Fig. 1. Experimental design of this research. (A) Scheme of assay by $q P C R$ analysis. (B) Two types of culture systems: suspension or adherent culture.

et al., 2017). We noted that the first step from the undifferentiated state toward definitive endoderm (DE) was the most important for efficient generation of functional beta cells; we achieved robust DE differentiation by adding FGF2, BMP4 and CHIR99021 (GSK3 Binhibitor) as well as Activin A to the medium. Almost all the cells were SOX17 (definitive endoderm marker) positive, and PDX1 (pancreatic progenitor marker) and NGN3 (endocrine progenitor marker) became positive for more than $90 \%$ of them. Although immunostaining revealed that insulin c-peptide was positive for about $30 \%$ of the cells, the glucose stimulated insulin secretion response of these cells was weak. We successfully overcame this problem by introducing 3D spheroid culture at the final step. About $30 \%$ of the cells were C-peptide positive in these spheroids, and the glucose responsive insulin secretion of these 3D cultured cells was enhanced twofold compared with adherent culture. Because of the importance of 3D structure for the function of pancreatic beta cells, we became interested in suspension culture.

For clinical applications of hES/iPS-beta cells, large amounts of cells are needed, and suspension culture is suitable for such large-scale production. Although suspension culture systems in self- renewal have been developed by several groups (Rungarunlert et al., 2009, Amit et al., 2010, Olmer et al., 2010,Singh et al., 2010, Olmer et al., 2012, Abbasalizadeh et al., 2012), many differentiation protocols for beta cells have been based on adherent culture mimicking the developmental stages (D'Amour etal., 2006, Maehr et al., 2009, Kunisada et al., 2012, Rezania et al., 2012). Recently, however, new protocols based on suspension culture throughout the entire process have been reported (Schulz et al., 2012, Pagliuca et al., 2014, Russ et al., 2015, Konagaya and Iwata, 2016, Mihara et al., 2017, Yabe et al., 2019). Viacyte, which is doing clinical trials on diabetes patients using encapsulated pancreatic progenitor cells (PEC-01) derived from human ESCs, reported a scalable suspension culture production system using gyration (Schulz et al., 2012). Melton's group also reported a differentiation protocol for functional hES-derived beta cells in large scale suspension culture using a spinner system (Pagliuca et al., 2014). We decided to use both suspension culture systems to characterize cells from adherent and suspension cultures and then compare them.

Definitive endoderm (DE), which is the innermost of the three principal germ layers and is generated from invaginating epiblast cells in the primitive streak during gastrulation, gives rise to the epithelial lining of the respiratory and digestive tracts, from which the thyroid, thymus, lungs, liver and pancreas arise along the anterior-posterior axis (Zorn and Wells, 2009). Because pancreatic beta-cells originate from DE, DE differentiation from hPSCs is the first critical process in differentiating hES/iPS-beta cells; therefore, much research has focused on this step (D'Amour etal., 2005. Mclean etal., 2007. Kunisada (B) et al., 2012. Loh et al., 2014, Ninomiya et al., 2015, Matsuno et al., 2016. Yabe et al., 2017). Although, we also quite recently reported the induction of islet-like cells from hiPS cells by suspension culture (Yabe et al., 2019), detailed comparison of DE differentiation between adherent and suspension cultures has not been published as far as we know. We focused on this first and critical step for differentiation to pancreatic $\beta$ cells.

In this study, we assumed two stages, posterior epiblast and primitive streak, before DE and examined the time course of gene expression of the putative markers of these stages. We demonstrated different patterns of expression during DE differentiation between suspension culture and adherent culture.

\section{Results}

\section{Expression of undifferentiated marker mRNA}

We first examined the proliferation of $4 \mathrm{M}$ and 454E2 in both adherent and suspension culture conditions. Adherent cultured cells increased about 1.5 -fold between 0 and $96 \mathrm{~h}$; suspension cultured cells increased about 2-fold between 0 and $96 \mathrm{~h}$ (Sup. Fig. 2).

To compare the gene expressions of adherent and suspension cultured hiPSCs during DE differentiation, we assumed two stages, 
posterior epiblast and primitive streak, before DE. Then we chose putative markers for these stages and examined their time courses of gene expression (qRT-PCR) at several timepoints $(0$, $12,24,48,72,96 \mathrm{~h}$ after $\mathrm{DE}$ induction) by quantitative RT-PCR (Fig. 1A). We used two iPSCs lines: 4M and 454E2. For suspension culture, $4 \mathrm{M}$ was mainly cultured in a spinner system;454E2 was cultured in a gyratory system (Fig. 1B). This differentiation protocol is summarized in Sup. Fig.1. Representative individual data are shown in Sup. Fig. S1-4 and the averages of fold induction data $(n=3)$ in Fig. 2-5. We first investigated the gene expression of undifferentiated PSCs markers OCT3/4, SOX2, and NANOG, because down-regulation of these genes' expression is important for progression of DE differentiation. As shown in Fig. 2 and Sup.Fig. 3, although OCT3/4 expression in the suspension culture was higher than in the adherent culture until $24 \mathrm{~h}$, a reduction of OCT3/4 expression started from $48 \mathrm{~h}$ in suspension culture, but it started at $72 \mathrm{~h}$ in adherent culture. The same pattern was noted in NONAG expression; the turning point for suspension culture was $48 \mathrm{~h}$, but it was $72 \mathrm{~h}$ for adhesion culture. Unlike OCT3/4 and NANOGexpression, SOX2expression had already decreased at $12 \mathrm{~h}$, and SOX2expression was lower in suspension culture than in adherent culture from 24 to $96 \mathrm{~h}$. These results indicate that expressions of the undifferentiated PSCs markers OCT3/4, SOX2 and NONOG were all downregulated in suspension culture earlier than in adherent culture.

\section{Expression of posterior epiblast marker mRNA}

Definitive endoderm is formed during gastrulation in the primitive streak, and the posterior epiblast is the area in which primitive streak emerges (Lu and Robertson 2001, Robb and Tam 2004). Because specification of the posterior epiblast is the initial step of this process, we next examined the expression profiles of FGF8 and NODAL, regarded as the first indicators of posterior pattern formation in the epiblast (Fig.3, Sup. Fig.4). These two genes were rapidly up-regulated from 12 to $24 \mathrm{~h}$, and stronger expression was observed in suspension culture than in adherent culture. Furthermore, these genes' expressions peaked at $24 \mathrm{~h}$ in the suspension culture, but at $48 \mathrm{~h}$ in adherent culture. These results suggest that
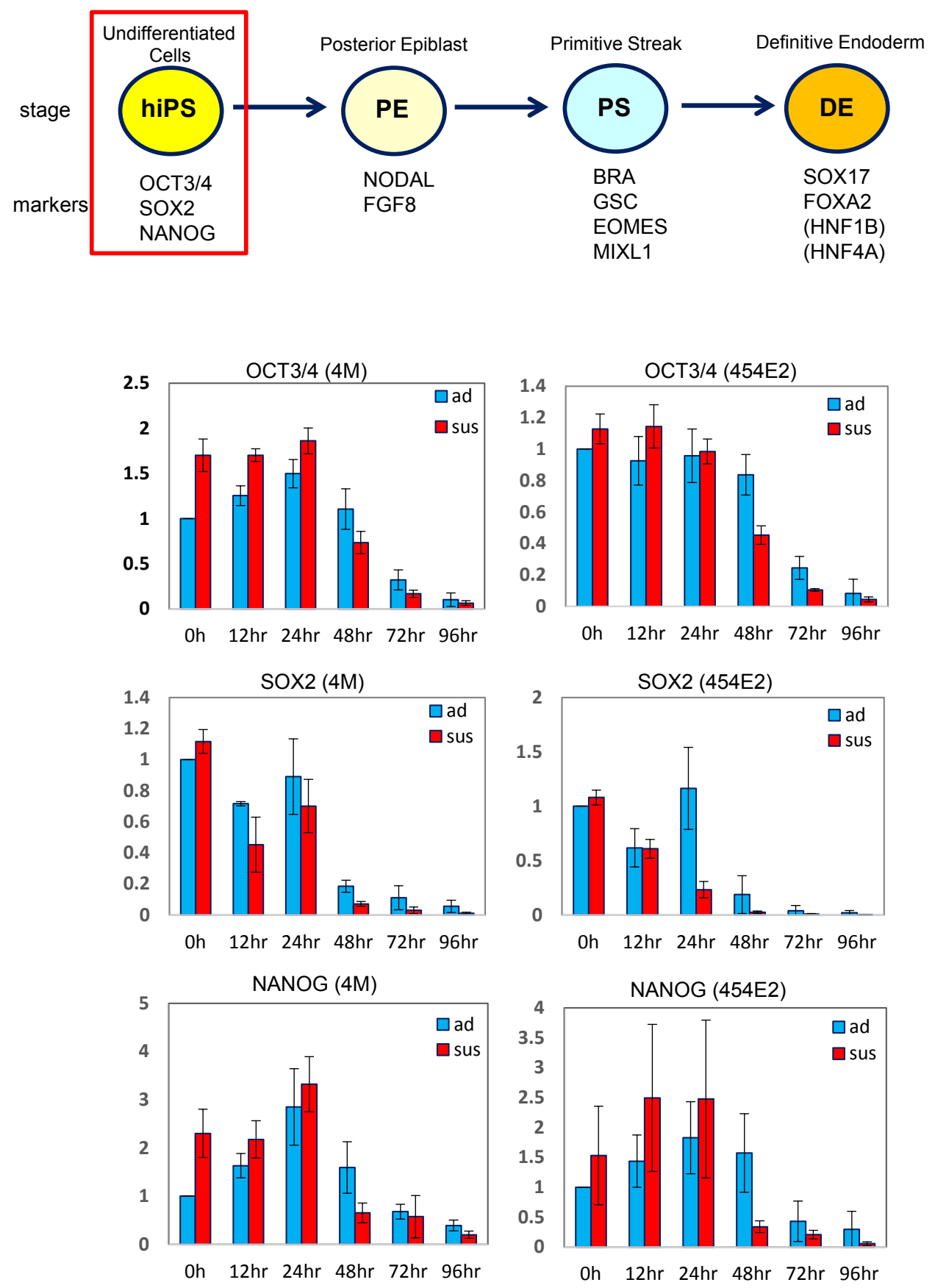

Fig. 2. Expression patterns of undifferentiated human induced pluripotent stem cell (hiPSC) markers. OCT3/4, SOX2 and NANOG expression was examined by qPCR at 0, 12, 24, 48, 72, $96 \mathrm{~h}$ after definitive endoderm differentiation in suspension or adherent culture using two hiPSC lines (4M and 454E2). Y-axis indicates fold induction. Relative fold induction of each gene was calculated by selecting one sample at a certain timepoint and setting its expression level as 1. Selected samples for standardization are as follows: ad(Oh) for OCT3/4 (4M), ad (Oh) for OCT3/4 (454E2), ad (Oh) for SOX2 (4M), ad (Oh), SOX2 (454E2), ad (Oh) for NANOG (4M), ad (Oh) for NANOG (454E2,). ad, adherent culture sample; sus, suspension culture sample.

pattern formation of the posterior epiblast occurred earlier in the suspension culture than in the adherent culture.

Expression of primitive streak marker mRNA

After patterning of the posterior epiblast, the primitive streak 
forms, so we investigated four primitive streak markers: Brachyury(BRA), goosecoid(GSC), Mix paired-like homeobox (MIXL1)and eomesodermin(EOMES) (Fig. 4, Sup. Fig.5). These markers' expressions were more enhanced in suspension culture than in adherent culture from $12 \mathrm{~h}$ to $24 \mathrm{~h}$. $\mathrm{A}$ remarkable difference was observed at 24 $\mathrm{h}$, especially in 454E2. BRA, which is the downstream target of WNT3a(Yamaguchi et al., 1999), is a good indicator of the progress of gastrulation toward $\mathrm{DE}$, because $B R A$ expression decreases and disappears in DE cells but persists in mesodermal cells after its peak. The peak of BRA expression was earlier in suspension culture (24h) than adherent culture ( $48 \mathrm{~h}$ ) and declined at $48 \mathrm{~h}$ in suspension culture. This shift of peak time may reflect the difference of progression speed of differentiation between suspension and adherent cultures.

\section{Expression of definitive endoderm marker mRNA}

Definitive endoderm cells are generated during gastrulation, so we next examined the expression patterns of DE markers such as SOX17and FOXA2 (Fig. 5, Sup.Fig. 6). Rapid up-regulation of SOX17 expression was observed at $48 \mathrm{~h}$ with higher expression in suspension cultures than in adherent cultures. Although the expression level in suspension cultures of SOX17peaked at 48 $\mathrm{h}$ and remained almost the same between 48 and $72 \mathrm{~h}$, that of SOX17 in adherent cultures peaked later at $72 \mathrm{~h}$ and was lower at $48 \mathrm{~h}$ than in suspension cultures. FOXA2 expression was up-regulated more and earlier in suspension cultures than in adherent cultures, and the higher expression level was sustained for 48-96 h.

\section{Expression of primitive gut tube marker mRNA}

Because the progression speed of differentiation was faster in suspension culture than in adherent culture, we surveyed the patterns of expression of primitive gut tube (PGT) markers such as HNF1B and HNF4A. As shown in Fig. 5 and Sup.Fig. 6, HNF1B expression was first activated at $48 \mathrm{~h}$ in suspension culture but only slightly in adherent culture, and it was remarkably enhanced at 72 $\mathrm{h}$ in suspension culture compared with adherent culture. This difference in expression level between suspension culture and adherent culture remained at $96 \mathrm{~h}$. Higher activation of HNF4A expression was observed at $72 \mathrm{~h}$ in suspension culture than in adherent culture, and there was a significant difference in its expression level at 96 $h$. These results suggest that a transition towards PGT occurred in suspension cultures earlier than in adherent cultures.

\section{Expression of representative genes at the protein level}

We examined expression patterns at the protein level by western blot (Fig. 6). OCT3/4 protein was down-regulated at $48 \mathrm{~h}$ in both sus- pension and adherent cultures. In 4M, OCT3/4 protein disappeared in the suspension culture but remained in the adherent culture at $96 \mathrm{~h}$. In 454E2, OCT3/4 protein was more reduced in suspension culture than in adherent culture at $48 \mathrm{~h}$ and lost in suspension culture but still present in adherent culture at $72 \mathrm{~h}$. We observed stronger SOX17 bands in suspension culture at $48 \mathrm{~h}$ in both 4M and 454E2. FOXA2 protein was detected in $4 \mathrm{M}$ at $24 \mathrm{~h}$ in suspension culture, earlier than in adherent culture, but no obvious difference in FOXA2 protein level was observed in 454E2. Weak HNF4A protein was detected in suspension cultures at $72 \mathrm{~h}$, and a denser HNF4A protein band was observed in suspension culture than in adherent culture at $96 \mathrm{~h}$. The HNF1B protein level did not differ between suspension culture and adherent culture (data not shown).

Next, as cell-based analyses, we performed flow cytometry and immunocytochemistry (Fig. 7, Sup. Fig. 7). Flow cytometric analysis showed that there are no clear differences in positive rates of surface DE marker CXCR4 between adherent and suspension cultures, both of which was more than $97 \%$ (Fig. 7). On the other hand, the numbers of positive cells for SOX17, FOXA2, HNF1B and HNF4A were higher in suspension cultures than in adherent 
cultures, and an especially remarkable difference was observed in 454E2 (Fig. 7) These results correspond to immunocytochemical ones (Sup. Fig. 7), in which positive cells were relatively uniformly distributed in aggregates. Taken together, these results suggest that the expressions of markers for protein levels also indicate earlier DE differentiation in suspension culture than in adherent culture.

\section{Discussion}

3D structure is critical for the function of pancreatic beta cells. In the present study, we compared the expressions of marker genes for developmental stages between suspension culture and adherent culture to uncover possible biological advantages of suspension culture in addition to the technical advantage of large scale culture. We considered the experimental design carefully, because it is critical for this study to maintain the same conditions between suspension culture and adherent culture. Cell interactions in 2D and 3D culture are basically different. In particular, PSCs are known to start differentiation after cell aggregation (embryoid body formation). Therefore, we did not use hanging drop methods to aggregate iPS cells immediately but rather adopted a gradual aggregation method from a single cell in suspension using spinner culture and gyratory culture, as described in Fig. 1B. We obtained relatively uniformly sized spheroids with both culture systems by adjusting the rotation speed. We were able to use the same medium and additives before and after the differentiation process in each set of experiments, although we used different basic media for 4M and 454E2. We regarded these spheroids and adherent cells as undifferentiated because we detected high expressions of OCT3/4, SOX2 and NANOG at the beginning of differentiation (Oh in Fig. 2). Proper circuit of undifferentiated marker gene expression is important for retaining undifferentiated PSCs and inhibiting differentiation of hPSCs (Boyer etal., 2005, Pardo et al., 2010, van den Berg et al., 2010). The fact that PS or DE marker genes were barely detected before differentiation indicates that these cells did not start endoderm differentiation automatically.

The initial step of DE differentiation is patterning of the posterior epiblast, because the primitive streak initially emerges in that area (Lu and Robertson 2001, Robb and Tam 2004). We chose FGF8 and NODAL as posterior epiblast marker genes and BRA, GSC, MIXL1 and EOMES as primitive streak marker genes. We examined their time course expressions and found that they expressed earlier in suspension culture than in adherent culture. The rapid up-regulation of these genes suggested that the posterior epiblast was specifying more strongly in suspension culture than in adherent culture and subsequently initiating transition to primitive streak.

Interestingly, these gene expressions were detected as early as $12 \mathrm{~h}$ after initiating differentiation and peaked
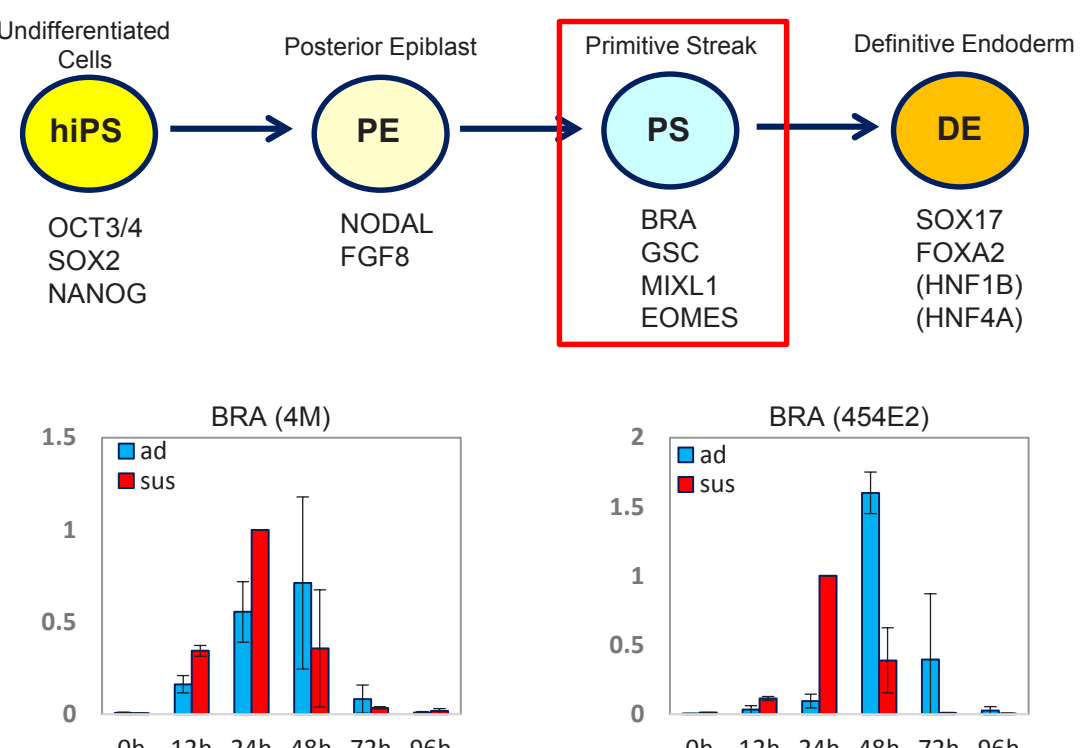

Oh $12 \mathrm{~h} 24 \mathrm{~h} \quad 48 \mathrm{~h} \quad 72 \mathrm{~h} 96 \mathrm{~h}$

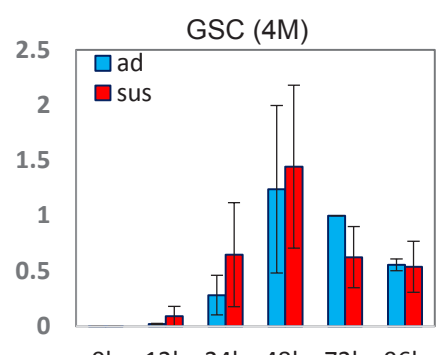

GSC (454E2)
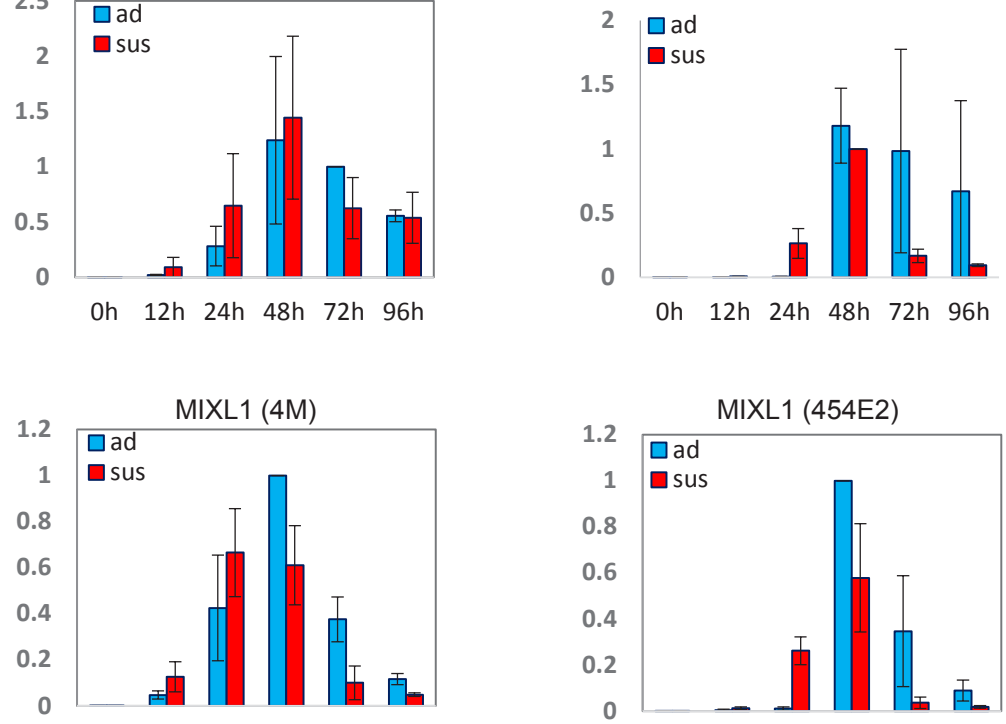

Oh $12 \mathrm{~h} 24 \mathrm{~h} 48 \mathrm{~h} 72 \mathrm{~h} 96 \mathrm{~h}$

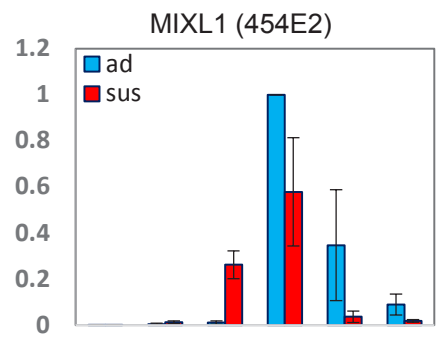

Oh $12 \mathrm{~h} \quad 24 \mathrm{~h} 48 \mathrm{~h} \quad 72 \mathrm{~h} 96 \mathrm{~h}$

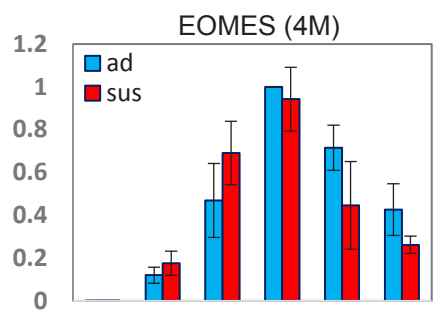

Oh $12 \mathrm{~h} \quad 24 \mathrm{~h} 48 \mathrm{~h} \quad 72 \mathrm{~h} 96 \mathrm{~h}$

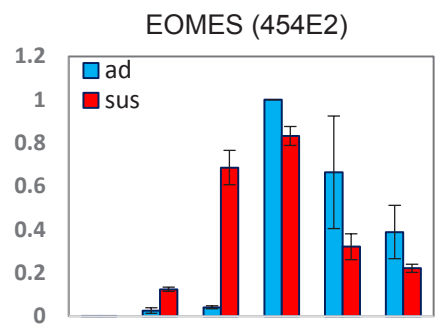

Oh $12 \mathrm{~h} \quad 24 \mathrm{~h} 48 \mathrm{~h} \quad 72 \mathrm{~h} 96 \mathrm{~h}$

Fig. 4. Expression pattern of posterior primitive streak markers. BRA, GSC, MIXL1 and EOMES expression was examined by qPCR at 0, 12, 24, 48, 72, $96 \mathrm{~h}$ in the same way as Figure 2. Selected samples for standardization are as follows: sus (24h) for BRA (4M), sus (24h) for BRA (454E2), ad (72h) for GSC (4M), sus (48h) for GSC (454E2), ad (48h) for MIXL1 (4M), ad (48h) for MIXL1 (454E2), ad (48h) for EOMES (4M), ad(48h) for EOMES (454E2). ad, adherent culture sample; sus, suspension culture sample. 

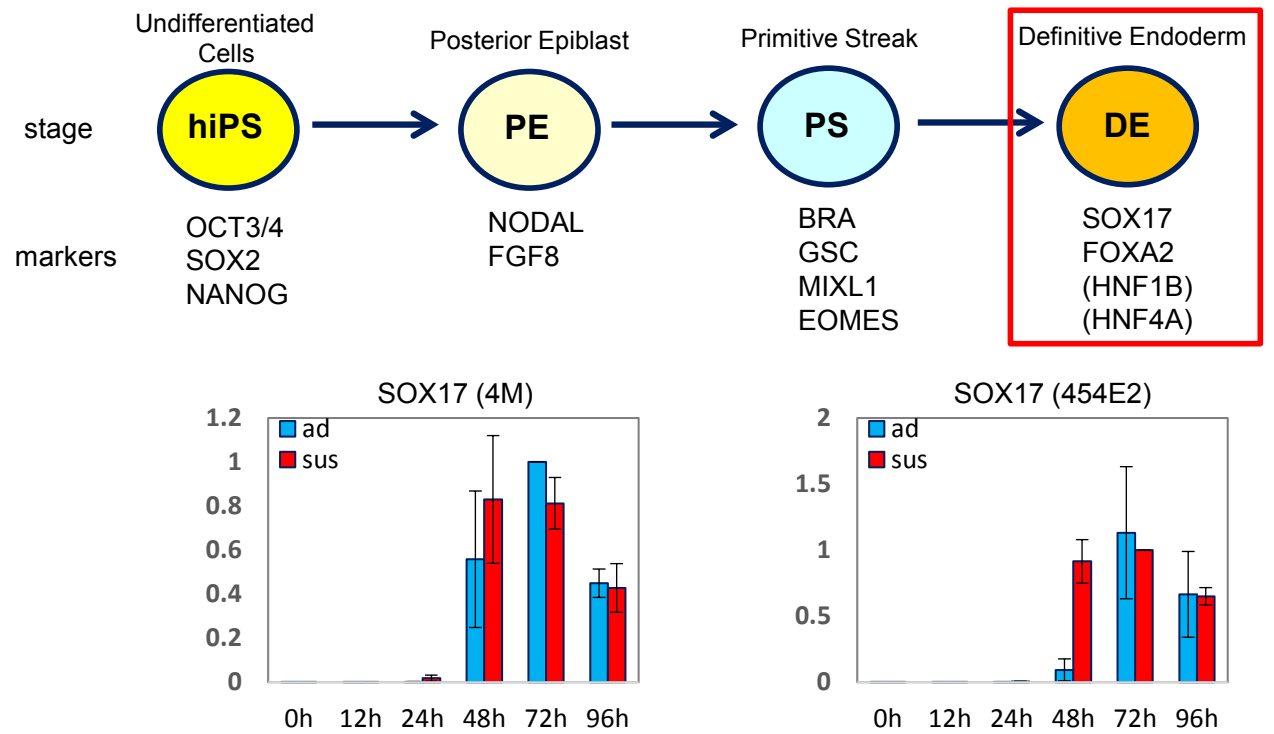

Oh $12 \mathrm{~h} 24 \mathrm{~h} 48 \mathrm{~h} 72 \mathrm{~h} 96 \mathrm{~h}$

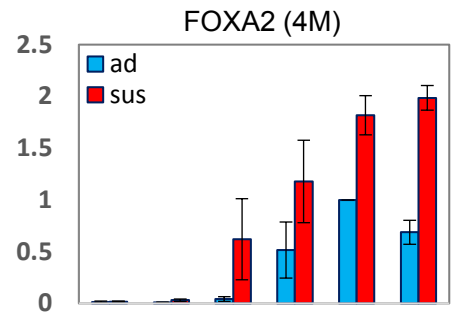

Oh $12 \mathrm{~h} 24 \mathrm{~h} 48 \mathrm{~h} 72 \mathrm{~h} 96 \mathrm{~h}$
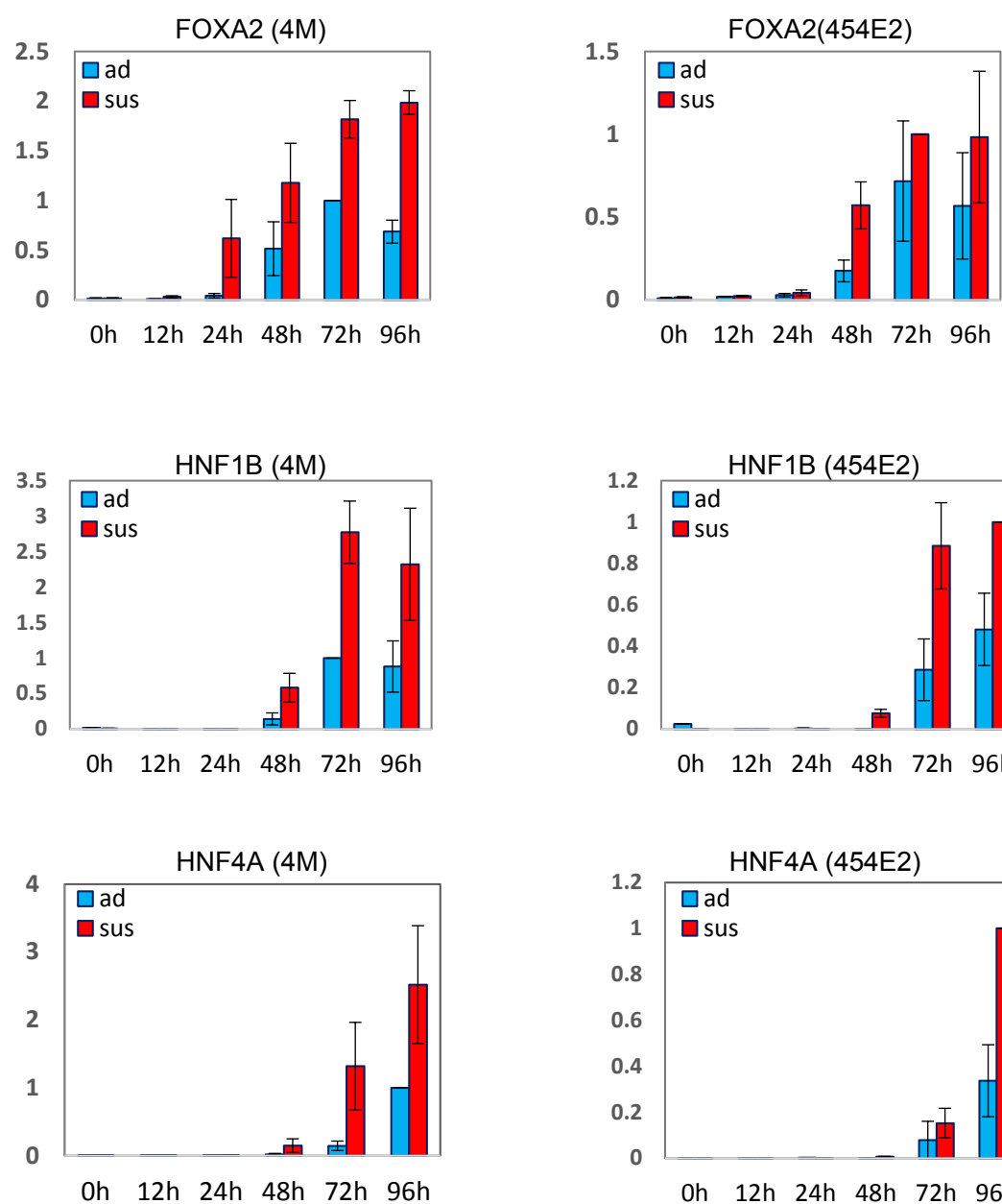

Oh $12 \mathrm{~h} 24 \mathrm{~h} 48 \mathrm{~h} 72 \mathrm{~h} 96 \mathrm{~h}$
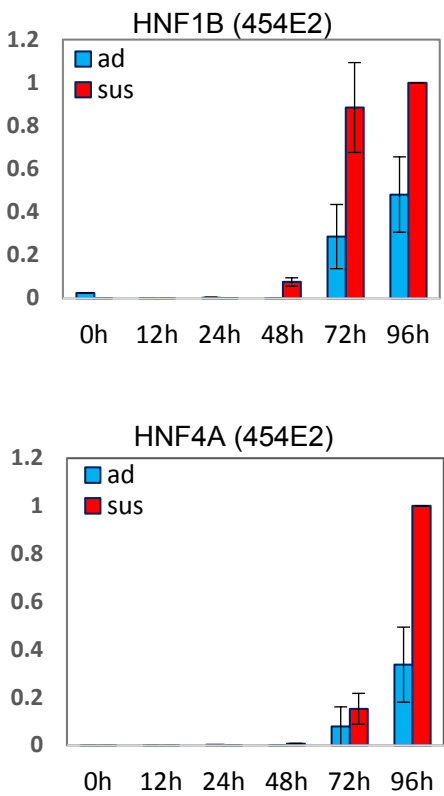

Fig. 5. Expression pattern of definitive endoderm and primitive gut tube markers. SOX17, FOXA2, HNF1B and HNF4A expression was examined by qPCR at 0, 12, 24, 48, 72, $96 \mathrm{~h}$ in the same way as Figure 2. Selected samples for standardization are as follows: ad (72h) for SOX17 (4M), sus (72h) for SOX17 (454E2), ad (72h) for FOXA2 (4M), sus (72h) for FOXA2 (454E2), ad (72h) for HNF1B (4M), sus (96h) for HNF1B (454E2), ad (96h) for HNF4A (4M), sus (96h) for HNF4A (454E2). ad, adherent culture sample; sus, suspension culture sample. at $24 \mathrm{~h}$ in suspension culture, even though undifferentiated hPSC marker gene expression was still high. It is generally thought that breakdown of this circuit due to down-regulation of undifferentiated hPSC marker gene expression triggers differentiation. Our results suggest that PE and PS differentiation processes start before undifferentiated hPSC marker gene expression shuts down. Of the three genes tested, SOX2 down-regulated first. This might reflect a previous report that OCT3/4 didn't block PS markers expression but inhibited DE markers expression; SOX2 repressed both PS and DE markers expression (Teo et al., 2011).

During gastrulation, epithelial epiblast cells undergo an epithelialmesenchymal transition (EMT) and give rise to mesoderm and endoderm (Kallri and Weinberg, 2009). As DE differentiation proceeds, expression of the epithelium marker E-cadherin decreases; in contrast, mesenchymal marker $\mathrm{N}$-cadherin expression increases (D'Amour et al., 2005). We also examined these genes' expression patterns and demonstrated the same behavior, in agreement with D'Amour et al., 2005. No clear differences in expression levels were observed between suspension and adherent cultures (data not shown). However, the expressions of DE markers and a later stage of DE marker SOX17 were initially stronger and peaked earlier at $48 \mathrm{~h}$ in suspension culture; they tended to decrease as differentiation proceeded. Stronger FOXA2 expression was also observed in suspension culture and continued to increase until $96 \mathrm{~h}$. These data parallel the report that SOX17 expression peaked faster than FOXA2expression and decreased after peak during $\mathrm{DE}$ differentiation (D'Amour et al., 2005). In addition to the DE markers HNF1B and HNF4A, both PGT markers of the following stage of DE had a faster run-up and retained higher expression in suspension culture. The temporal dynamics of these PGT markers indicate that the transition from $D E$ toward PGT proceeded faster in suspension culture. Of note, HNF4A mRNA is transcribed by two promoters, $\mathrm{P} 1$ or $\mathrm{P} 2$, which are used in different tissues and at different times during develop- 
ment (Harries et al., 2008, Walesky and Apte 2015, Tuncer and Banerjee 2017). During liver development, although the P2 promoter is used initially, as differentiation proceeds, the promoter switches from $\mathrm{P} 2$ to $\mathrm{P} 1$, and only HNF4A mRNA transcribed with the P1 promoter is observed in adult liver (Harries et al., 2008, Walesky and Apte 2015). Although only the P2 promoter is used in adult pancreas, both P2 and P1 promoter-derived HNF4A mRNA are detected in fetal pancreas (Harries et al., 2008). Therefore, the expression profiles of $\mathrm{P} 2$ and $\mathrm{P} 1$ promoter-derived HNF4A mRNA are interesting as indicators of differentiation state in addition to that of PGT marker. Recently it was reported that P2-derived HNF4A mRNAsignificantly increased, but expression of P1-derived HNF4A mRNA did not change during DE differentiation in hiPSCs (Hanawa et al., 2017). We observed that both $\mathrm{P} 2$ and P1-derived HNF4A mRNA increased in both suspension and adherent cultures but that suspension cultures expressed these mRNAs at higher levels than adherent cultures during DE differentiation (data not shown). Although further research is needed to resolve this question, this difference in behavior of $\mathrm{P} 1$-derived HNF4A between this previous report and our results might be due to differentiation conditions. The higher expression of P2 and P1-derived HNF4A mRNA in suspension cultures might reflect differences in differentiation state. Moreover, the balance between the expression level of P2-derived HNF4A and that of P1-derived HNF4AmRNA might become a new indicator of DE cell subtype (Loh et al., 2014, Matsuno et al., 2016).

Although we examined only a limited number of marker genes and used only two hiPSCs lines, we found similar patterns of expression in mRNA and protein levels. Our data clearly show that expression of marker genes was faster and more strongly up-regulated in suspension culture than in adherent culture. To explain these results, we hypothesized an effect of ECM because interaction with proper ECM is thought to be important to maintaining undifferentiated states in hPSCs. Matrigel was actually used for adherent cultures in this study, because it is supposed to maintain the self-renewal ability strongly and stably (Xu et al., 2001). Therefore, undifferentiated states might be so tightly maintained in adherent culture that it takes more time to start differentiation. It is conceivable that downregulation of undifferentiated markers and transition from undifferentiated to differentiated states occur faster in suspension cultures due to the less contact with ECM. ECM has been suggested to play important roles not only in retaining undifferentiated states but also in DE differentiation. It was reported that fibrillar fibronectin was necessary for loss of pluripotency and that fibronectin-coated substrate improved DE differentiation in comparison with collagen and laminin substrate (Brafman et al., 2012, Taylor-Weiner et al., 2013). We confirmed that expression levels of fibronectin were higher in suspension cultures than in adherent cultures (data not shown). Interestingly, spheroid formation enhanced the expression and meshwork of fibronectin compared with monolayer in the case of human adipose-derived stem cells (Cheng et al., 2012). Another possibility is the effect of insulin/PI3K signaling. It is reported that Activin A specified DE only when insulin/PI3K signaling was suppressed (Maclean et al., 2007, Yu et al., 2015). We found that the expression level of IRS1, which is the effector of insulin signaling, was lower in suspension culture than adherent cultures (data not shown). Suppression of insulin/ PI3K signaling might also contribute to the effective DE induction in our case. It is also reported that 3D culture of differentiated hPSCs such as hepatocyte or pancreatic endocrine progenitors
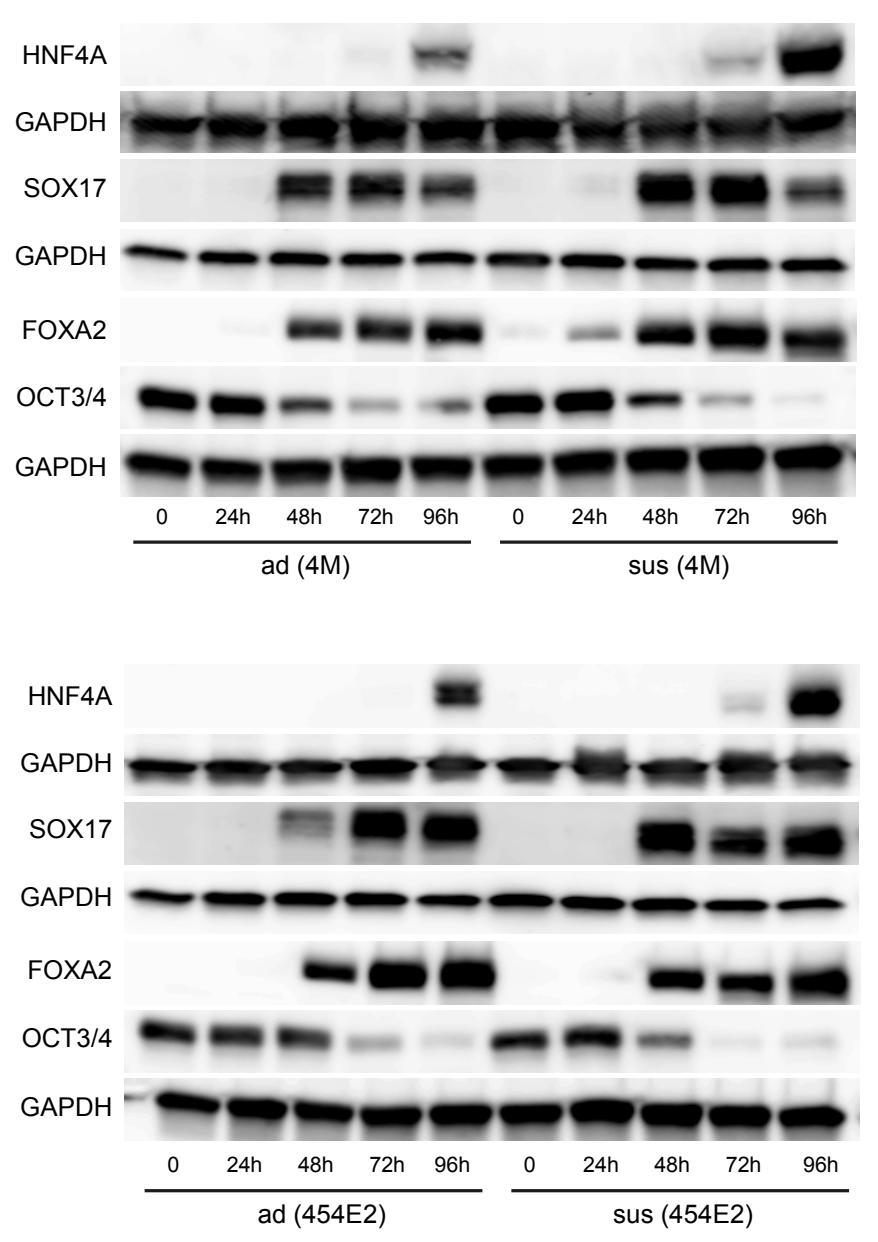

Fig. 6. Protein expression patterns of representative definitive endoderm (DE) and primitive gut tube (PGT) markers. Protein expression was examined by Western blot at 0,24, 48, 72, $96 \mathrm{~h}$ in suspension or adherent cultured using two hiPSCs lines (4M and 454E2). HNF4a was used as a PGT marker, and SOX17 and FOXA2 were used as DE markers. OCT3/4 was used as an undifferentiated marker. GAPDH was used as a control. The amount of sample protein loaded on each lane in the gel was as follows: HNF4A (44 $\mu \mathrm{g})$, SOX17 (1.5 $\mu \mathrm{g})$, FOXA2 and OCT3/4 (8.0 $\mu \mathrm{g})$. ad, adherent culture sample; sus, suspension culture sample.

promote function or maturation (Sengupta et al., 2014, Takeuchi et al., 2014, Yabe et al., 2017). Taken together, we can conclude that suspension culture favors DE differentiation. This argument is further supported by our quite recent data that iPS-derived islet-like cells generated by suspension culture ameliorate hyperglycemia in diabetic mice and that they produce human insulin c-peptide at a rate 30 times higher than our adherent based culture in mouse plasma (Yabe et al., 2019). Further study will be needed to elucidate the precise mechanism of differentiation in 3D culture.

\section{Materials and Methods}

\section{Undifferentiated iPSC culture}

The human iPSCs line TKDN4-M (4M), which was established from neonatal fibroblasts using retrovirus, was a kind gift from Dr. M. Ohtsu at The Institute of Medical Science, The University of Tokyo, and was cultured according to our previous protocol (Yabe et al., 2015). 4M was cultivated 


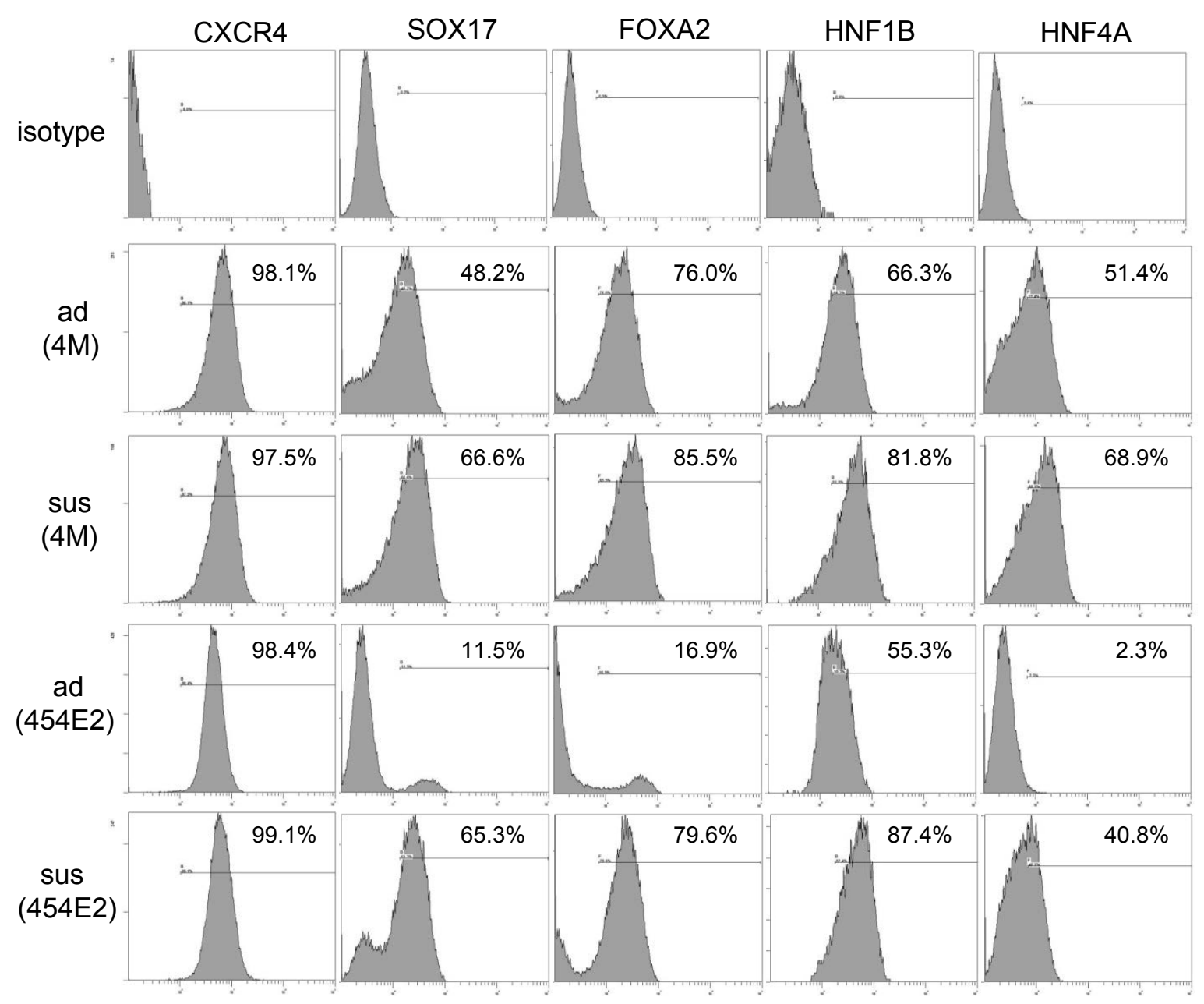

Fig. 7. Flow cytometric analysis of definitive endoderm (DE) and primitive gut tube (PGT) markers. Flow cytometry was performed with cells harvested $96 \mathrm{~h}$ after DE differentiation in suspension or adherent culture using two hiPSCs lines (4M and 454E2). CXCR4, SOX17 and FOXA2 were used as DE markers and HNF1B and HNF4A were used as PGT markers. Isotype, isotype control; ad, adherent culture sample; sus, suspension culture sample.

on mitomycin-C treated SNL feeder cells in hiPSs medium (DMEM/Ham's F12(Wako, Osaka, Japan) containing 20\% Knockout Serum Replacement (KSR; GIBCO BRL, Palo Alto, CA, USA), 1xMEM non-essential amino acids (NEAA; Wako), 0.5x penicillin and streptomycin (PS; Wako), 0.055

\section{TABLE 1}

\section{PRIMERS USED FOR qRT-PCR}

\begin{tabular}{lll} 
gene & forward & reverse \\
\hline BRA & CGT CTC CTT CAG CAA AGT CAA G & CCC AAC TCT CAC TAT GTG GAT TC \\
EOMES & GTC GAG GTT CTT ACC AGA GGA AG & GGG TGT CTC TAT CCA AGA AGA GC \\
FGF8 & ATC CGG ACC TAC CAA CTC TAC AG & GTC TCC ACG ATG AGC TTT GC \\
FOXA2 & GAG ATC TAC CAG TGG ATC ATG GAC & CAC CTT CAG GAA ACA GTC GTT G \\
GSC & ACC GCA CCA TCT TCA CTG AC & TAAACC AGA CCT CCA CTT TCT CC \\
HNF1b & GAG ATC CTC CGA CAA TTC AAC C & AAA CAG CAG CTG ATC CTG ACT G \\
HNF4a & AAG AGA TCC ATG GTG TTC AAG GAC & AGG TAG GCA TAC TCATTG TCA TCG \\
MIXL1 & CCC TTG CCT CTA GCT TCT CAA C & CTC CTG ACT TCA GGT GAT CCA C \\
NANOG & CGA AGA ATA GCA ATG GTG TGAC & GTT GCT CCA GGT TGA ATT GTT C \\
NODAL & AGA GTC TGC TGA AAC GTT ACC AG & CCA CAT TCT TCC ACG ATC ATG \\
OAZ1 & GTC AGA GGG ATC ACA ATC TTT CAG & GTC TTG TCG TTG GAC GTT AGT TC \\
OCT3/4 & CGC TTC AAG AAC ATG TGT AAG CTG C & CTC TCA CTC GGT TCT CGA TAC TG \\
SOX2 & ATA AGT ACT GGC GAA CCA TCT CTG & AAT TAC CAA CGG TGT CAA CCT G \\
SOX17 & TAC ACA CTT CCT GGA GGA GCT AAG & CCA AAC TGT TCA AGT GGC AGA C \\
\hline
\end{tabular}

mM 2-mercaptoehtanol (2-ME; GIBCO), and $7.5 \mathrm{ng} / \mathrm{ml}$ recombinant human fibroblast growth factor 2 (FGF2; Peprotech, Rocky Hill, NJ, USA). The human iPSCs line 454E2, which was established from adolescent dental pulp using episomal vectors, was a kind gift from CiRA, Kyoto University, and was maintained on vitronectin (GIBCO) in Essential8 medium (E8; GIBCO).

\section{In vitro differentiation}

Undifferentiated 4M was detached from feeder cells using CTK solution, rinsed with D-PBS several times, and then dissociated into single cells using Accumax (Innovative Cell Technologies, San Diego, USA). For adherent culture, dissociated $4 \mathrm{M}$ were plated on Matrigel-coated 6 well plates in mTeSR1 (VERITAS, Tokyo, Japan) containing 10uM Y-27632(Cayman Chemical, Ann Arbor, MI, USA), cultured for 1-2 days until they reached $\sim 90 \%$ confluence, and further cultured in hiPSs medium for 1 day. The next day, DE induction was initiated. For suspension culture, dissociated 4M was seeded at a density of one million cells per $\mathrm{ml}$ in $30 \mathrm{ml} \mathrm{mTeSR} 1$ with $10 \mu \mathrm{M}$ Y-27632 in the spinner flask (ABLE, Tokyo, Japan) at a rotation rate of $45 \mathrm{rpm}$. The medium was replaced the next day, and, one day later, it was exchanged for hiPS medium. The next day, DE induction was started.

For adherent culture of 454E2, undifferentiated cells were dissociated using Accutase (Innovative Cell Technologies) and then seeded on Matrigelcoated 6-well plates in E8 with $10 \mu \mathrm{M}$ Y-27632. The cells were cultivated for 2 days and then cultured in hiPS medium for 1 day. DE induction was started the next day. For suspension culture, dissociated 454E2 cells were 
seeded into ultra-low attachment 6-well plates at a density of $10^{6} \mathrm{cell} / \mathrm{sl}$ in $4 \mathrm{ml}$ E8 medium including $10 \mu \mathrm{M}$ Y-27632 on orbital rotators set at 90 rpm. After overnight culture, the medium was exchanged. The next day, E8 was replaced with hiPS medium for 1 day; then DE induction was initiated. Human iPSCs were differentiated to DE according to following protocol: Day1-2: RPMI 1640 supplemented with $0.25 \%$ bovine serum albumin (BSA), 0.4x PS, $1 \mathrm{mM}$ sodium pyruvate, 1x NEAA, $0.055 \mathrm{mM}$ 2-ME, 80 $\mathrm{ng} / \mathrm{ml}$ recombinant human activin A (Peprotech), $50 \mathrm{ng} / \mathrm{ml}$ FGF2, $20 \mathrm{ng} /$ $\mathrm{ml}$ recombinant bone morphogenetic protein 4 (BMP4; Peprotech), $3 \mu \mathrm{M}$ CHIR99021 (Biovision, Milpitas, CA, USA). Day3: RPMI 1640 supplemented with $0.25 \%$ BSA, $0.4 x \mathrm{PS}, 1 \mathrm{mM}$ sodium pyruvate (SP; Wako), $1 \mathrm{x}$ NEAA, $0.055 \mathrm{mM}, 2-\mathrm{ME}, 80 \mathrm{ng} / \mathrm{ml}$ recombinant human activin A. Day4: RPMI 1640 supplemented with $0.5 \% \mathrm{KSR}, 0.25 \% \mathrm{BSA}, 0.4 \mathrm{x} \mathrm{PS}, 1 \mathrm{mM}$ $\mathrm{SP}, 1 \mathrm{x}$ NEAA, $0.055 \mathrm{mM}$ 2-ME, $80 \mathrm{ng} / \mathrm{ml}$ recombinant human activin A. For 454E2, insulin-transferrin-selenium-ethanolamine (ITS-X, GIBCO) was further added to this medium $(1: 100,000)$. This differentiation protocol is summarized in Sup. Fig.1.

\section{Quantitative RT-PCR}

Total RNA was isolated and purified using Isogen. The cDNA was synthesized with PrimeScript II reverse transcriptase using random nonamers and oligos (dT18). Quantitative RT-PCR reactions were carried out on CFX96 Touch Deep Well (Bio-Rad, Hercules, CA, USA) using GoTaq qPCR master mix (Promega, Madison, WI, USA). Relative quantification was performed against a standard curve, and the expression levels of target genes were normalized against that of the housekeeping gene, ornithine decarboxylase antizyme (OAZ1). For the time course comparison of gene expression, one of the samples at a certain time point was selected, and relative fold induction was calculated for each gene. The primer sequence is listed in Table1.

\section{Western blotting}

Cells were collected in RIPA Buffer (Wako) with protease inhibitors (Roche, Basel, Switzerland), sonicated, and centrifuged. Whole cell lysate protein concentrations were determined by a BCA protein assay (TakaRa). Proteins were boiled in sample buffer (BIO-RAD) and loaded onto Mini-PROTEAN®TGX ${ }^{\text {TM }}$ Gels (BIO-RAD) separated by SDS-PAGE. Protein bands were transferred to Trans-Blot ${ }^{\circledR}$ Turbo $^{\mathrm{TM}}$ membranes (BIORAD), which were then immersed in TBST containing the first antibody. Then the membranes were treated with Blocking One (Nacalai Tesque, Kyoto, Japan). After washing, the membranes were next immersed in the second antibody and reacted with Super Signal ${ }^{\circledR}$ West Femto Maximum Sensitivity Substrate (Thermo Fisher Scientific, Waltham, MA). The bands were observed by LAS 4000 mini (FujiFilm, Tokyo, Japan).

Western blotting was performed using anti-OCT3/4(1:1000, BD Bioscience), anti-FoxA2 (1:1000, Cell Signaling), anti-SOX17(1:5000, R\&D Systems), anti-HNF1 $\beta$ (1:1000, Proteintech) anti-HNF4 $\alpha$ (1:1000, Cell Signaling) and anti-GAPDH (1:5000, Thermo Fisher Scientific). Horseradish peroxidase-conjugated second antibody $(1: 2000)$ was purchased from Santa Cruz Biotechnology (Santa Cruz, CA).

\section{Flow cytometry}

Differentiated cells were dissociated into single cells using accutase and washed with RPMI1640. Cells were fixed with 4\% paraformaldehyde at RT for $30 \mathrm{~min}$ and washed with PBS several times. For surface marker CXCR4 staining, cells were incubated in blocking buffer (PBS $+0.1 \%$ triton- $\mathrm{X}+3 \% \mathrm{FBS}$ ) at RT for $1 \mathrm{~h}$ and then incubated in blocking buffer with directly conjugated primary antibody (APC anti-human CD184 (CXCR4), $1: 20$, Biolegend, CA, USA) at $4{ }^{\circ} \mathrm{C}$ for $1 \mathrm{~h}$. Stained cells were washed with blocking buffer and re-suspended in PBS $+1 \%$ BSA and then analyzed on a Gallios flow cytometer (Beckman Coulter, CA, USA) using Gallios software. For intracellular staining (SOX17, FOXA2, HNF1B and HNF4A), fixed cells were incubated in methanol at $4^{\circ} \mathrm{C}$ for $10 \mathrm{~min}$ and washed with blocking buffer several times. Cells were incubated in blocking buffer at RT for $1 \mathrm{~h}$ and then incubated in blocking buffer with 1:100 diluted primary antibody
(anti-FoxA2 (Cell Signaling), anti-SOX17(R\&D Systems), anti-HNF1 $\beta$ (Proteintech) anti-HNF $4 \alpha$ (Cell Signaling)) at $4^{\circ} \mathrm{C}$ overnight. Cells were washed with blocking buffer several times and incubated in blocking buffer with 1:400 diluted secondary antibody (donkey anti-rabbit Alexa 647 or donkey anti-goat Alexa 647, Thermo Fisher Scientific). Stained cells were washed with blocking buffer and re-suspended in PBS+ $1 \%$ BSA and then analyzed as mentioned above.

\section{Acknowledgments}

The authors are grateful to Dr. Barbara Lee Smith Pierce (University of Maryland University College, Adelphi, MD, USA) for her help with the preparation of this manuscript.

This work was supported by grants from the National Center for Global Health and Medicine (27A1201) to HO and (29A1016) to SGY and by the AMED Grant for Centers for Clinical Application Research on Specific Disease/Organ (Type B) to HO.

\section{References}

ABBASALIZADEHS, LARIJANIMR, SAMADIANA, BAHARVANDH(2012). Bioprocess development for mass production of size-controlled human pluripotent stem cell aggregates in stirred suspension bioreactor. Tissue Eng C Methods 11: 831-851.

AMIT M, CHEBATH J, MARGULETS V, LAEVSKY I, MIROPOLSKY Y, SHARIKI K, PERI M, BLAIS I, SLUTSKY G, REVEL M, ITSKOVITZ-ELDOR J (2010). Suspension culture of undifferentiated human embryonic and induced pluripotent stem cells. Stem Cell Rev. 6: 248-259.

BOYER L.A, LEE, T.I, COLE M.F, JOHNSTONE S.E, LEVINE S.S, ZUCKER J.P, GUENTHER M.G, KUMAR R.M, MURRAY H.L, JENNER R.G (2005). Core transcriptional regulatory circuitry in human embryonic stem cells. Cell 122: 947-956.

BRAFMAN DA, PHUNG C, KUMAR N, WILLERT K (2013). Regulation of endodermal differentiation of human embryonic stem cells through integrin-ECM interactions. Cell death diff 20: 369-381

CHENG NC, WANG S, YOUNG TH (2012). The influence of spheroid formation of human adipose-derived stem cells on chitosan films on stemness and differentiation capabilities. Biomaterials 33: 1748-1758

D'AMOUR K.A, AGULNICK A.D, ELIAZER S, KELLY O.G, KROON E, BAETGE E.E (2005). Efficient differentiation of human embryonic stem cells to definitive endoderm. Nat Biotechnol 23: 1534-1541.

D'AMOUR K.A, BANG A.G, ELIAZER S, KELLY O.G, AGULNICK A.D, SMART N.G MOORMAN M.A, KROON E, CARPENTER M.K, BAETGE E.E (2006) Production of pancreatic hormone-expressing endocrine cells from human embryonic stem cells. Nat Biotechnol 24: 1392-1401.

HANAWA M, TAKAYAMA K, SAKURAI F, TACHIBANA M, MIZUGUCHI H (2017). Hepatocyte Nuclear Factor 4 Alpha promotes definitive endoderm differentiation from human induced pluripotent stem cells. Stem Cell Rev 13: 542-551.

HARRIES L.W, LOCKE J.M, SHIELDS B, HANLEY N.A, HANLEY K.P, STEELE A, NJØLSTAD P.R, ELLARD S, HATTERSLEY A.T (2008). The diabetic phenotype in HNF4A mutation carriers is moderated by the expression of HNF4A isoforms from the P1 promoter during fetal development. Diabetes 57: 1745-52.

KALLURI R and WEINBERG R.A (2009). The basics of epithelial-mesenchymal transition. J Clin Invest 119: 1420-1428.

KONAGAYAS, IWATAH (2016). Reproducible preparation of spheroids of pancreatic hormone positive cells from human iPS cells: An in vitro study. Biochim Biophys Acta 1860: 2008-2016.

KUNISADA Y, TSUBOOKA-YAMAZOE N, SHOJI M, HOSOYA M (2012). Small molecules induce efficient differentiation into insulin-producing cells from human induced pluripotent stem cells. Stem Cell Res 8: 274-84.

LOH K.M, ANG L.T, ZHANG J, KUMAR V, ANG J, AUYEONG J.Q, LEE K.L, CHOO S.H, LIM C.Y.Y, NICHANE M, TAN J, NOGHABI M.S, AZZOLA L, NG E.S, DURRUTHY-DURRUTHY J, SEBASTIANO V, POELLINGER L, ELEFANTYA.G, STANLEY E.G, CHEN Q, PRABHAKARS, WEISSMAN I.L, LIM B (2014). Efficient endoderm induction from human pluripotent stem cells by logically directing signals controlling lineage bifurcations. Cell Stem Cell 14: 237-252.

LU C.C, BRENNAN J, ROBERTSON E.J (2001). From fertilization to gastrulation: Axis formation in the mouse embryo. Curr Opin Genet Dev 11: 384-392. 
MAEHR R, CHEN S, SNITOW M, LUDWIG T, YAGASAKI L, GOLAND R, LEIBEL R.L, MELTON D.A (2009). Generation of pluripotent stem cells from patients with type 1 diabetes. Proc Natl Acad Sci USA 106: 15768-15773.

MATSUNO K, MAE S.I, OKADA C, NAKAMURA M, WATANABE A, TOYODA T, UCHIDA E, OSAFUNE K (2016). Redefining definitive endoderm subtypes by robust induction of human induced pluripotent stem cells. Differentiation 5:281-290.

MCLEANA.B, D'AMOURK, JONES K.L, KRISHNAMOORTHY M, KULIK M.J REYNOLDS D.M, SHEPPARD A.M, LIU H, XUY, BAETGE E.E, DALTON S (2007)Activin A efficiently specifies definitive endoderm from human embryonic stem cells only when phosphatidylinositol 3-kinase signaling is suppressed. Stem Cell25: 29-38.

MIHARA Y, MATSUURA K, SAKAMOTO Y, OKANO T, KOKUDO N, SHIMIZU T (2017). Production of pancreatic progenitor cells from human induced pluripotent stem cells using a three-dimensional suspension bioreactor system. J Tissue Eng Regen Med, 11: 3193-3201

NINOMIYA H, MIZUNO K, TERADA R, MIURA T, OHNUMA K, TAKAHASHI S, ASASHIMA M, MICHIUE T (2015). Improved efficiency of definitive endoderm induction from human induced pluripotent stem cells in feeder and serum-free culture system. In vitro Cell Dev Biol Anim 51: 1-8.

OLMER R, HAASE A, MERKERT S, CUI W, PALECEK J, RAN C, KIRSCHNING A, SCHEPERT, GLAGES, MILLERK, CURNOW EC, HAYES ES, MARTINU (2010). Long term expansion of undifferentiated human iPS and ES cells in suspension culture using a defined medium. Stem Cell Res 5: 51-64.

OLMER R, LANGE A, SELZER S, KASPER C, HAVERICH A, MARTIN U, ZWEIGERDT R (2012). Suspension culture of human pluripotent stem cells in controlled, stirred bioreactors. Tissue Eng C Methods 18: 772-784

PAGLIUCA F.W, MILLMAN J.R, GURTLER M, SEGEL M, VAN DERVORT A, RYU J.H, PETERSON Q.P, GREINER D, MELTON D.A (2014). Generation of functional human pancreatic beta cells in vivo. Cell 159: 428-439.

PARDO M, LANG B, YU L, PROSSER H, BRADLEY A, BABU M.M, CHOUDHARY J (2010). An expanded Oct4 interaction network: Implications for stem cell biology, development, and disease. Cell Stem Cell 6: 382-395.

REZANIA A, BRUIN JE, RIEDEL MJ, MOJIBIAN M, ASADI A, XU J, GAUVIN R, NARAYAN K, KARANU F, O'NEIL JJ, AO Z, WARNOCK GL, KIEFFER TJ (2012). Maturation of human embryonic stem cell-derived pancreatic progenitors into functional islets capable of treating pre-existing diabetes in mice. Diabetes 61: 2016-2029

REZANIAA, BRUIN JE, ARORA P, RUBIN A, BATUSHANSKYI, ASADI A, O'DWYER S, QUISKAMP N, MOJIBIAN M, ALBRECHT T, YANG YH, JOHNSON JD, KIEFFER TJ (2014). Reversal of diabetes with insulin-producing cells derived in vitro from human pluripotent stem cells. Nat Biotechnol 32: 1121-1133.

ROBB L, AND TAM P.P (2004). Gastrulation organizer and embryonic patterning in the mouse. Semin Cell Dev Biol 15: 543-554.

RUNGARUNLERTS, TECHAKUMPHU M, PIRITYMK, DINNYESA (2009). Embryoid body formation from embryonic and induced pluripotent stem cells: Benefits of bioreactors. World J Stem Cells, 1: 11-21

RUSS HA, PARENT AV, RINGLER JJ, HENNINGS TG, NAIR GG, SHVEYGERT M, GUO T, PURI S, HAATAJA L, CIRULLI V, BLELLOCH R, SZOT GL, ARVAN P, HEBROK M (2015). Controlled induction of human pancreatic progenitors produces functional beta-like cells. EMBO J. 34: 1759-1772.

SCHULZ TC, YOUNG HY, AGULNICK AD, BABIN MJ, BAETGE EE, BANG AG,
BHOUMIK A, CEPA I, CESARIO RM, HAAKMEESTER C, KADOYA K, KELLY JR, KERR J, MARTINSON LA, MCLEAN AB, MOORMAN MA, PAYNE JK, RICHARDSON M, ROSS KG, SHERRER ES, SONG X, WILSONAZ, BRANDON EP, GREEN CE, KROON EJ, KELLY OG, D'AMOUR KA, ROBINS AJ (2012). A scalable system for production of functional pancreatic progenitors from human embryonic stem cells. Plos One 7: e37004.

SENGUPTA S, JOHNSON B.P, SWANSON S.A, STEWART R, BRADFIELD C.A, THOMSON J.A (2014). Aggregate cultures of human embryonic stem cell-derived hepatocytes in suspension are an improved in vitro model for drug metabolism and toxicity testing. Toxi Sci 1: 236-245.

SINGH H. MOK P. BALAKRISHNAN T. RAHMAT S.N. ZWEIGERDT R (2010). Upscaling single cell-inoculated suspension culture of human embryonic stem cells. Stem Cell Res 4: 165-179.

TAKEUCHI H, NAKATSUJI N, SUEMORI H (2014). Endodermal differentiation of human pluripotent stem cells to insulin-producing cells in 3D culture. Sci Rep $4: 4488$.

TAYLOR-WEINER H, SCHWARZBAUER JE, ENGLER AJ (2013). Defined extracellular matrix components are necessary for definitive endoderm induction. Stem Cells 31: 2084-2094.

TEO A.K.K, ARNOLD S.J, TROTTER M.W.B, BROWN S, ANG L.T, CHNG Z, ROBERTSON E.J, DUNN N.R, VALLIER L (2011). Pluripotency factors regulate definitive endoderm specification through eomesodermin. Genes Dev25:238-250.

TUNCER SINEMAND BANERJEE SREEPARNA (2017). HNF4A (Hepatocyte Nuclear Factor 4 alpha). Atlas Genet Cytogenet Oncol Haematol 21: 44-51.

VAN DEN BERG D.L, SNOEK T, MULLIN N.P, TATES A, BEZSTAROSTI K, DEMMERS J, CHAMBERS I, POOT R.A (2010). An Oct4-centered protein interaction network in embryonic stem cell. Cell Stem Cell 6: 369-381.

WALESKY C, APTE U (2015). Role of Hepatocyte Nuclear Factor 4alpha (HNF4alpha) in cell proliferation and cancer. Gene Expr 16: 101-108.

XU C, INOKUMA MS, DENHAM J, GOLDS K, KUNDU P, GOLD JD, CARPENTER MK (2001). Feeder-free growth of undifferentiated human embryonic stem cells. Nat Biotechnol 19: 971-974.

YABE S.G, IWASAKIN, YASUDAK, HAMAZAKIT.S, KONNO M, FUKUDAS, TAKEDA F, KASUGA M, OKOCHI H (2015). Establishment of maturity-onset diabetes of the young-induced pluripotent stem cells from a Japanese patient. J Diabetes Invest 6: 543-547.

YABE S.G, FUKUDA S, TAKEDA F, NASHIRO K, SHIMODA M, OKOCHI H (2017). Efficient generation of functional pancreatic beta-cells from human induced pluripotent stem cell. J Diabetes 9: 168-179.

YABE SG, FUKUDA S, NISHIDA J, TAKEDA F, NASHIRO K, OKOCHI H (2019) Induction of functional islet-like cells from human iPS cells by suspension culture. Regen Ther. 10: 69-76.

YAMAGUCHI T.P, TAKADA S, YOSHIKAWA Y, WU N, MCMAHON A.P (1999). T (Brachyury) is a direct target of Wnt3a during paraxial mesoderm specification. Genes Dev 13: 3185-3190.

YU JS, RAMASAMY TS, MURPHY N, HOLT MK, CZAPIEWSKI R, WEI SK, CUI W (2015). PI3K/mTORC2 regulates TGF- $\beta /$ Activin signalling by modulating Smad2/3 activity via linker phosphorylation. Nat Commun 6: 7212.

ZORN A.M and WELLS J.M(2009). Vertebrate endoderm development and organ formation. Annu Rev Cell Dev Biol 25: 221-251. 


\section{Further Related Reading, published previously in the Int. J. Dev. Biol.}

Pluripotent human stem cells: Standing on the shoulders of giants

Ivan Damjanov and Peter W Andrews

Int. J. Dev. Biol. (2016) 60: 321-325

https://doi.org/10.1387/ijdb.160437id

Comparative epigenetic evaluation of human embryonic stem and induced pluripotent cells

Raha Favaedi, Maryam Shahhoseini, Mahammad Pakzad, Sepideh Mollamohammadi and Hossein Baharvand

Int. J. Dev. Biol. (2016) 60: 103-110

https://doi.org/10.1387/ijdb.140332ms

Bone morphogenetic protein 4 promotes craniofacial neural crest induction from human pluripotent stem cells

Sumiyo Mimura, Mika Suga, Kaori Okada, Masaki Kinehara, Hiroki Nikawa and Miho K. Furue

Int. J. Dev. Biol. (2016) 60: 21-28

https://doi.org/10.1387/ijdb.160040mk

SCNT versus iPSCs: proteins and small molecules in reprogramming

Fei Han, Xia Li, Dandan Song, Shaoshuai Jiang, Qun Xu and Yunhai Zhang

Int. J. Dev. Biol. (2015) 59: 179-186

https://doi.org/10.1387/ijdb.150042fh

Generation of pluripotent stem cells via protein transduction

Xia Li, Pengfei Zhang, Chao Wei and Yunhai Zhang

Int. J. Dev. Biol. (2014) 58: 21-27

https://doi.org/10.1387/ijdb.140007XL

Long-term serial cultivation of mouse induced pluripotent stem cells in serum-free and feeder-free defined medium

Sachiko Yamasaki, Kou Nabeshima, Yusuke Sotomaru, Yuki Taguchi, Hanae Mukasa, Miho K. Furue, J. Denry Sato and Tetsuji Okamoto

Int. J. Dev. Biol. (2013) 57: 715-724

https://doi.org/10.1387/ijdb.130173to

Faithful reprogramming to pluripotency in mammals - what does nuclear transfer teach us?

Julien Maruotti, Alice Jouneau and Jean-Paul Renard

Int. J. Dev. Biol. (2010) 54: 1609-1621

https://doi.org/10.1387/ijdb.103195jm
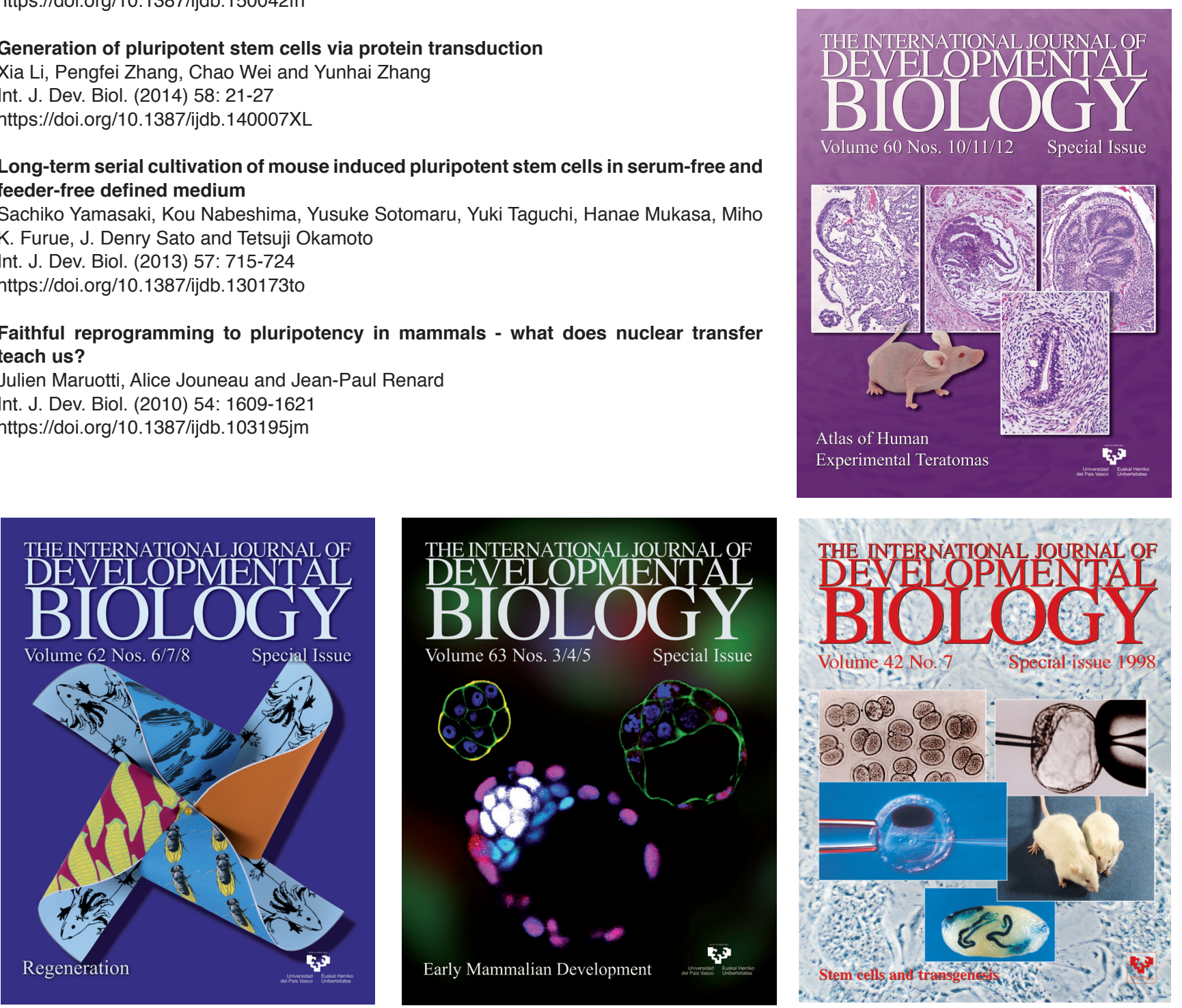